\title{
Sensitivity Curve of Decision-Making Process of The Company
}

\author{
Karel Chadt ${ }^{1}$; Martin Petř́íček ${ }^{2}$ \\ The Institute of Hospitality Management, \\ ${ }^{1}$ Department of Marketing, \\ ${ }^{2}$ Department of Economy and Economics, \\ Svídnická 506, 18100 Prague 8, Czech Republic \\ e-mail: ${ }^{1}$ chadt@vsh.cz; ${ }^{2}$ petricek@vsh.cz
}

\begin{abstract}
This article focuses on the issue of the sensitivity curve as an indicator of risk during decision-making process. The aim of this article is to present the measurement capabilities for sensitivity of the decision-making process within the issue of the use of quantitative methods in managerial decision making. The approach that is presented in the article uses the measurement of the sensitivity of the decision-making model to its input parameters. The whole decision-making process is a multiple-criterion and to determine a compromise variant there is Weighted Sum Approach (WSA) method used. This article uses the coefficient that determines the percentage change that is necessary to choose the second best option. In addition this approach is supported by formation of sensitivity curve. This curve represents the change in value of the output (using method WSA) when changing the selected input parameter of decision-making process. To build a sensitivity curve there is probabilistic simulation approach (Monte Carlo method) used.
\end{abstract}

\section{Keywords}

Sensitivity curve; Risk analysis; Monte Carlo simulation; Multiple-criteria decision making.

\section{Introduction}

The article focuses on an alternative method of sensitivity determination in decision-making processes of manager's decision making. Given the importance of the problem solution, the whole process is based on multi-criteria decision making. Weighted Sum Approach (WSA) is used primarily for selected multi-criteria decision-making process [1], [2]. To measure, the sensitivity of decision-making process in this article, the authors use a risk indicator. The riskiness of the decision-making process focuses only on the riskiness of individual variants. This is measured for example by probability, statistical characteristics or at-risk type of indicators. The lastly mentioned group is considered in the contemporary literature as the group that best describes the risk indicators of the individual variants. The most commonly used indicator is Value-at-Risk (VaR), but many others can be found such as Profit-at-Risk, Earnings-at-Risk, Cash Flow-at-Risk, etc. [3], [4], [5]. For the use of the VaR indicator, the basic statistical characteristics of the mean value, variance, standard deviation and variation coefficient are sufficient. The risk of the decision-making process is measured in this article by coefficient $\alpha$, which represent the percentage change in the inputs (criteria) needed for choosing another variant. This problem illustrates multiple-criteria decision analysis (MCDA) [6], [7]. 


\section{$1 \quad$ Research Objective}

The objectives of this article can be divided into two main aims. The first aim is to determine the coefficient $\alpha$ in general. This coefficient can be used as alternative methods for measuring the risk of the decision-making process. The second aim is focusing on setting the sensitivity curve. This curve combined percentage change in input (criteria) and percentage change in output (measured by WSA utility function).

\section{$2 \quad$ Research Methods}

This article uses multi-criterion decision-making approaches and also probabilistic simulation represented by Monte Carlo simulation approach. The WSA method, which is chosen for the multi-criterion evaluation of the variants, was chosen mainly because it uses the utility function that maximizes its value as a rating criterion. The utility function is linear and is compiled at interval $[0,1]$. The predicted linearity of the output utility function as an evaluation criterion is appropriate for measuring its sensitivity. The WSA assumes the use of a criteria matrix whose elements are replaced by the utility value of the $X_{i}$ while evaluating based on criteria of the $Y_{j}$. The output function of the utility should then have the form for the maximization criteria shown in Formula (1)

$$
u\left(X_{i}\right)=\sum_{j=1}^{k} v_{j} \times \frac{y_{i j}-D_{i}}{H_{j}-D_{j}},
$$

where $Y$ represents the criteria, $D$ is the lowest and $H$ is the highest value of the criterion $Y, v$ represents the weight of the given criterion. Index $i$ represents the row and index $j$ represents the column in the criterion matrix.

\section{$2.1 \quad$ Risk Measurement}

The risk of decision-making process is then performed using sensitivity analysis by the coefficient $\alpha$. This represents the desired percentage change of the input criteria when the value of the utility function $u\left(X_{i}\right)$ compromise variant reaches the level of the second worse variant in the decision-making process. This is a condition shown in Formula (2)

$$
\Delta u(X)=u\left(X_{1}\right)-u\left(X_{2}\right),
$$

where index 1 means chosen variant (based on WSA) and index 2 represents the second worse variant in the decision-making process. The difference in the utility function of two alternative variants is equal to the desired change in the value of the utility function. In the mono-criterion decision-making process, a non-negation condition would still have to be given, but it is irrelevant given the nature of the function using the WSA method. Graphically, we can simply interpret this problem by using Figure 1. 


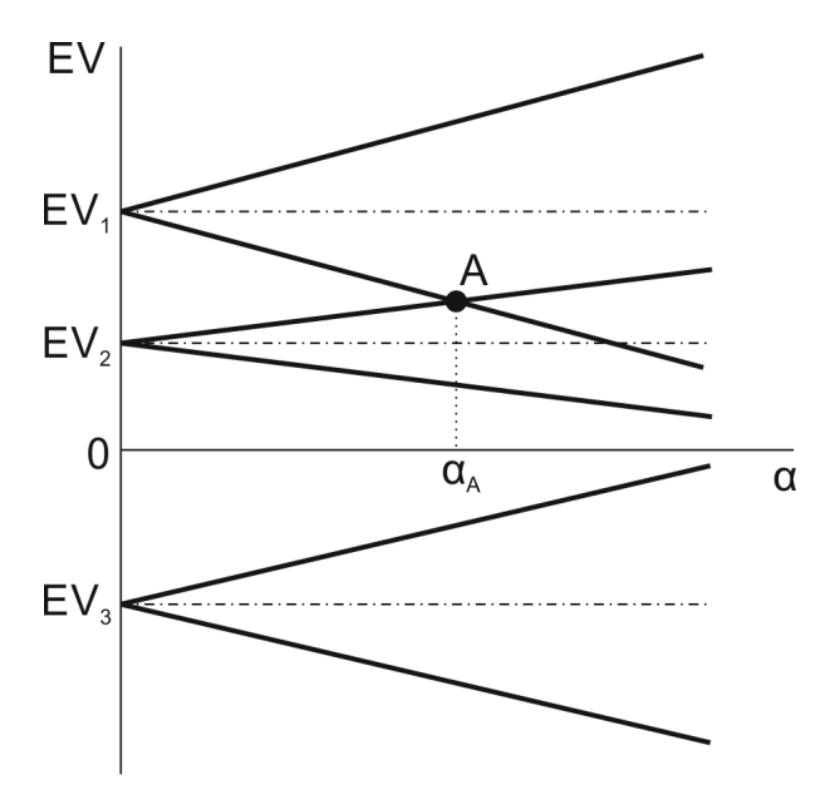

Source: Own

Fig. 1: Sensitivity measured by $\alpha$

In Figure 1 the vertical axis shows the utility function value (measured by expected value $(E V)$ of three different options) and the horizontal axis the value of the coefficient $\alpha$. Then the value of $\alpha_{A}$, represents the situation where the decision-maker, based on the utility function $u\left(X_{1}\right)$ and $u\left(X_{2}\right)$, is in a situation of the same utility value for those two variants. The higher $\alpha_{A}$ value then means the choice of option 2, because $u\left(X_{2}\right)$ is greater. The whole issue is therefore concentrating on looking for the coefficient $\alpha$, where for the first criterion (compromise variant) the condition (3) applies

$$
\alpha_{1} \times\left(v_{1 j} * \frac{y_{1 j}-D_{1}}{H_{j}-D_{j}}\right)+\sum_{j=2}^{k} v_{i} \times \frac{y_{i j}-D_{i}}{H_{j}-D_{j}}=u\left(X_{2}\right),
$$

where $y$ are the individual criteria and $v$ marks the weighting of these criteria if $i=1$ means the best option.

\subsection{Monte Carlo Simulation}

This article uses the probabilistic simulation called Monte Carlo. This kind of simulation could be used for risk analysis [8] or it is also used in process management [5], [9]. This simulation approach generates a high number of scenarios based on probabilistic distribution. The great advantage of this approach is that we can determine our own probabilistic distribution based on different kinds of inputs [10]. Simulation process is based on congruent generator (4)

$$
X_{n+1}=\left(a X_{n}+c\right) \bmod m,
$$

where $\bmod m$ is an integer residue after division; $a, c$, and $m$ are selected constants. The number of simulation cycles is set to 1000000 trials.

\subsection{Application}

In order to determine the coefficient $\alpha$, the simulation approach uses the Monte Carlo probability method. Within this approach, the properties of the solved model were set as follows. First, the calculation of the WSA's final utility function was compiled. This function 
was then multiplied by the coefficient $\alpha$, which has the basic value $\alpha=1$ and does not affect the resulting value of $u\left(X_{1}\right)$. Crystal Ball software has been used to solve the problem. Within the probability simulation, the uniform distribution was set for the coefficient value. In this case the value is 0.2 , see Figure 2 .

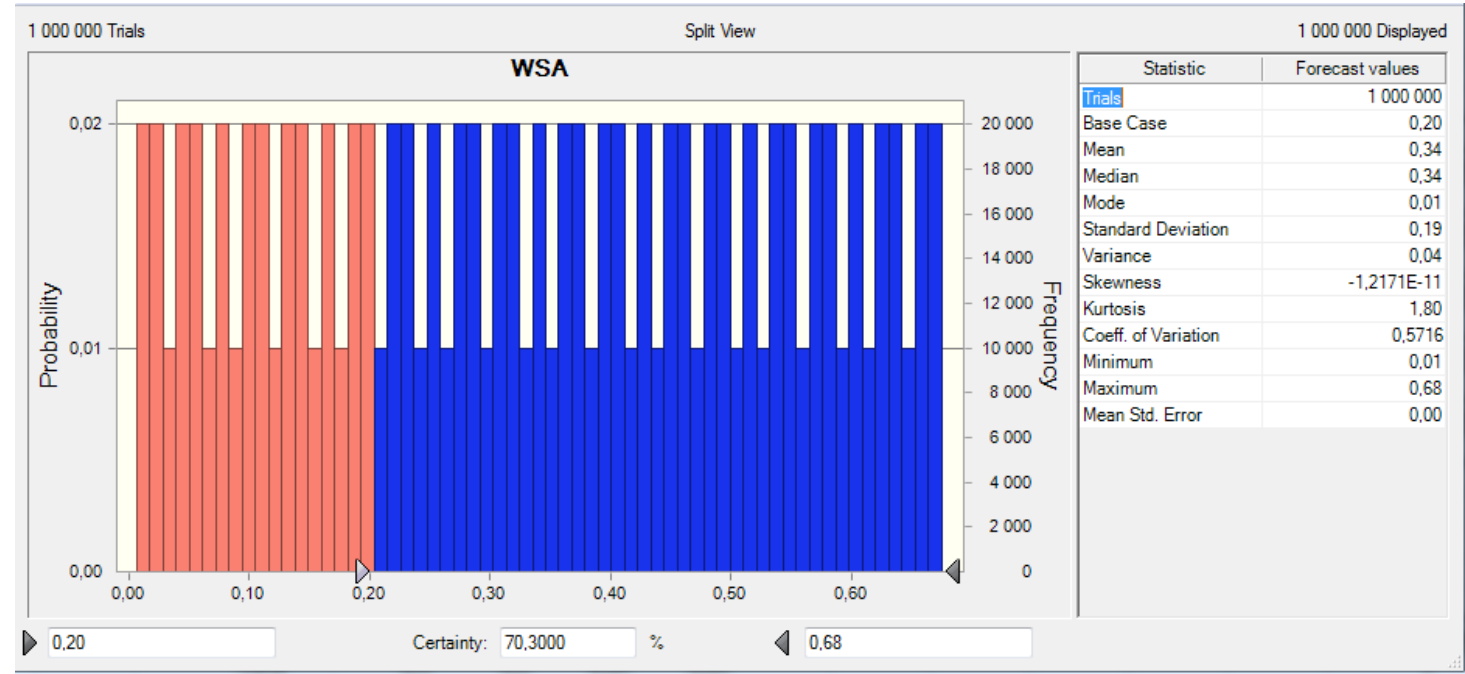

Source: Own

Fig. 2: Using simulation to determine $\alpha$

The perceived percentage change of the input criteria (coefficient $\alpha$ ) is basically the probability value at which the value of the WSA utility reaches values in the interval [0; $u\left(X_{2}\right)$ ]. In our case, this probability is 1 - certainty, which means that $\alpha=1-0.703=29.7 \%$.

This means, that probability of choosing another then the best option is $29.7 \%$. Additional approach of risk measuring lies in a simple sensitivity analysis with the use of Crystal Ball software. In this article, one-factor sensitivity analysis is used, with the help of the Monte Carlo simulation approach. These outputs then represent the sensitivity of the individual criteria to the output evaluation function of $u\left(X_{\mathrm{i}}\right)$. The article also focuses on how this sensitivity changes with a change in the value of each criterion. This change was always one percentage point, and its output was both a new utility feature and a new percentage representation of the sensitivity of the individual entry criteria. Measurements were made on twenty decision-making processes with the different number of criteria (from 3 to 6) and with different characteristics of these criteria. The evaluation was always based on the WSA method. The output values of the change in sensitivity were always followed for the criterion on which the chosen variant was the most sensitive. The main result is represented in the chart shown in Figure 3. 


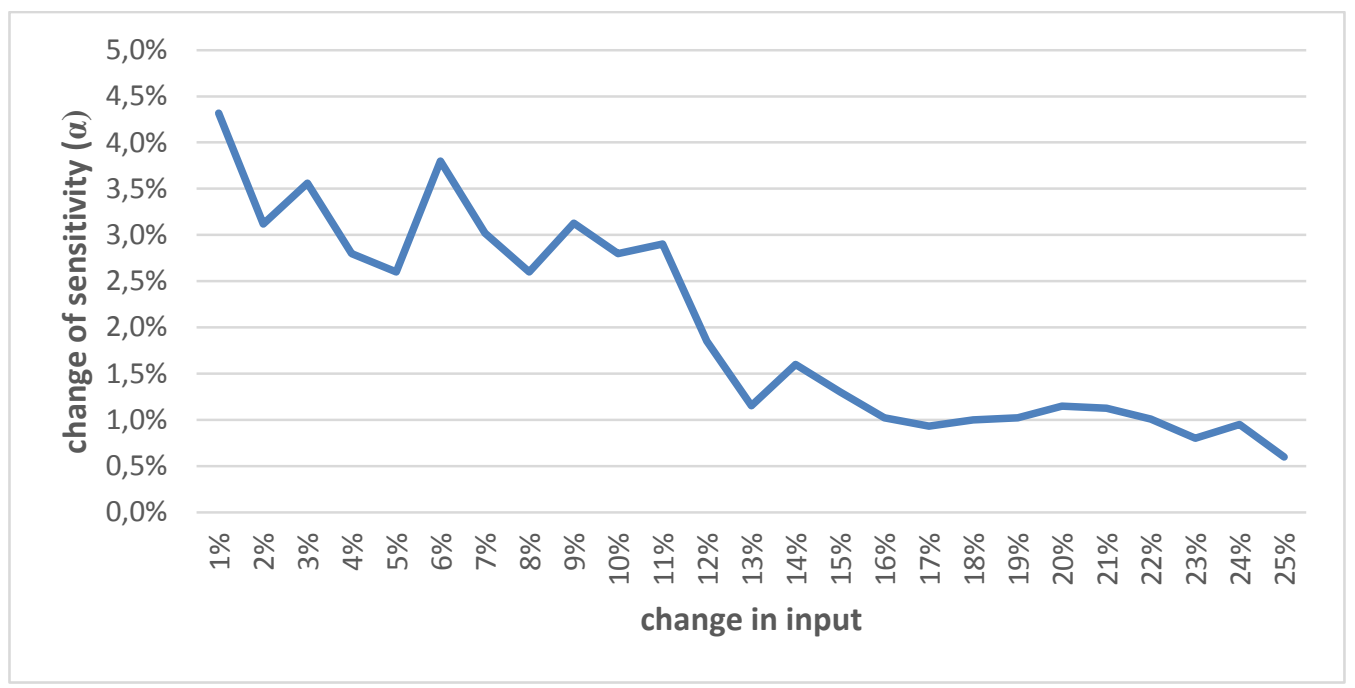

Source: Own

Fig. 3: Relation between change in $\alpha$ and change in input

In the chart in Figure 3 we can see that with greater change in input (it means criteria) the change in the sensitivity is decreasing but it is still positive. The total sensitivity with the change in input is therefore increasing but this sensitivity curve will be concave.

The last result of this article is the average sensitivity curve based on twenty different decision-making processes shown in Figure 4.

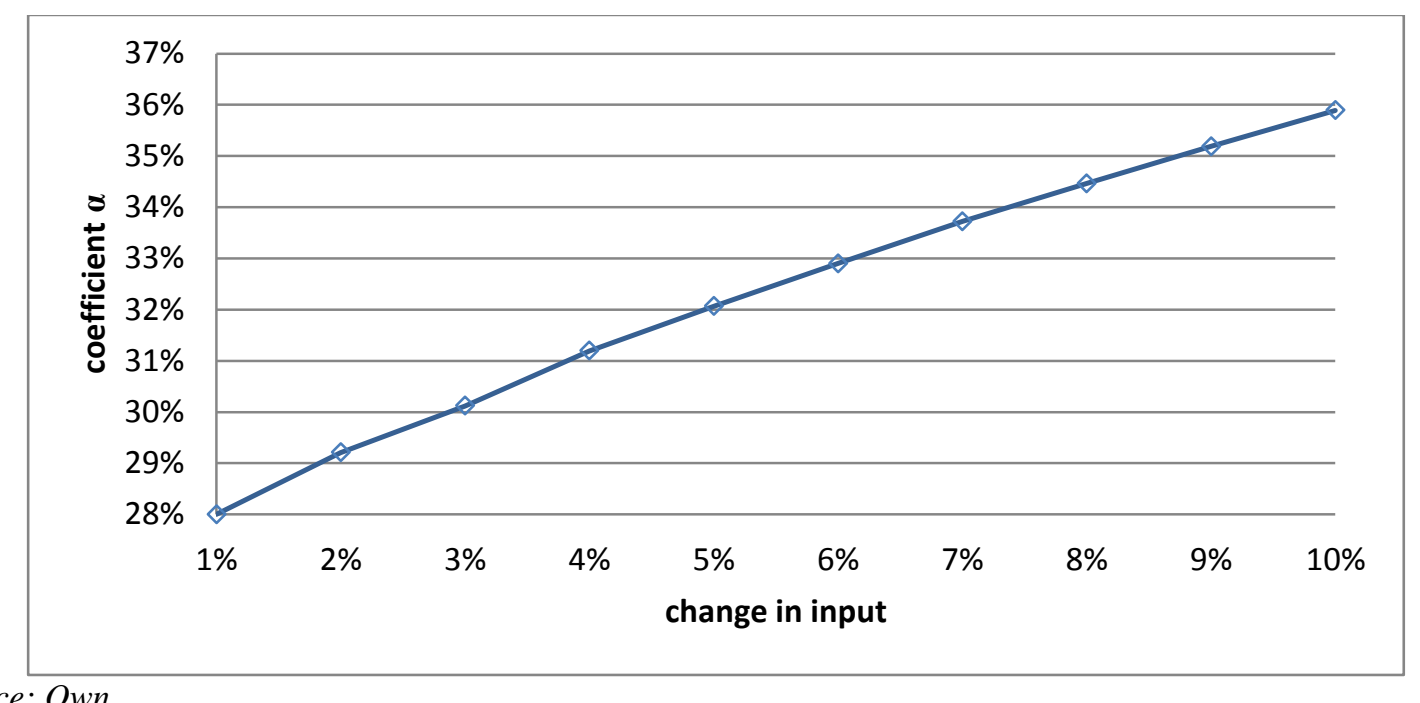

Source: Own

Fig. 4: Sensitivity curve

The chart in Figure 4 represents the final sensitivity curve based on average value of coefficient $\alpha$ which the article uses for measuring the risk of decision-making process.

\section{Conclusion}

The article presents two problem solutions, which are related. Firstly, it presents an alternative approach to measuring the risk of the entire decision model and further solves the sensitivity of the model on its input criteria. All investigations are conducted on decision-making processes that are evaluated using the WSA utility function. One of the main results of this article is coefficient $\alpha$ which has been computed using Monte Carlo simulation approach. With the help of Crystal Ball software, this article presents computation of this coefficient in twenty different decision-making processes. This coefficient measure the risk of this process 
by the probability, which is needed for choosing another (not the best) option. This article also works more with this result. There is also analysis of this coefficient made and the conclusion from this analysis says that sensitivity is not the same for the different percentage change of criteria. If we increase the change in the input the change of the sensitivity is decreasing. Therefore the sensitivity curve is upward sloping but concave function.

\section{Literature}

[1] SAATY, T. L. The Analytic Hierarchy Process. New York: McGraw-Hill International Book Company, 1980, 287 p.

[2] LIU, P.; XIA, J., CHI, P.: A method of multi-attribute decision making under risk based on interval probability. Journal of Intelligent \& Fuzzy Systems. 2014, Vol. 26, Issue 6, pp. 3005-3011. ISSN 10641246. DOI: 10.3233/IFS-130966

[3] STREET, A.: On the Conditional Value-at-Risk Probability-Dependent Utility Function. Theory and Decision. 2010, Vol. 68, Issue 1-2, pp. 49-68. ISSN 0040-5833. DOI: $\underline{10.1007 / \mathrm{s} 11238-009-9154-2}$

[4] AVEN, T.: Risk Analysis. Assessing Uncertainties Beyond Expected Values and Probabilities. Chichester, England; Hoboken, 2008. ISBN: 978-0-470-51736-9.

[5] PEREIRA, E. S. et al.: Methodology of risk analysis by Monte Carlo Method applied to power generation with renewable energy. Renewable Energy. 2014, Vol. 69, pp. 347355. ISSN 0960-1481. DOI: 10.1016/j.renene.2014.03.054

[6] WALLENIUS J. et al.: Multiple-criteria decision making, multiattribute utility theory: recent accomplishments and what lies ahead. Management Science. 2008, Vol. 54, Issue 7, pp. 1336-1349. DOI: $10.1287 /$ mnsc.1070.0838

[7] BRAGGE, J. et al.: Bibliometric Analysis of Multiple Criteria Decision Making/Multiattribute Utility Theory. IXX International MCDM Conference Proceedings. Lecture Notes in Economics and Mathematical Systems, Vol. 634. Springer, Berlin. 2010, pp. 259-268. DOI: 10.1007/978-3-642-04045-0_22

[8] FOTR, J.; HNILICA, J.: Aplikovaná analýza rizika ve finančním managementu a investičním rozhodování. 2., aktualiz. a rozš. vyd. Praha: Grada Publishing, 2014, 299 p. ISBN9788024751047.

[9] SAVAGE, S.: The flaw of averages: why we underestimate risk in the face of uncertainty. Hoboken, N. J.: John Wiley \& Sons, 2009. ISBN 9780471381976.

[10] PETříČEK, M.; SOCHU゚RKOVÁ, M.: The Use of Monte Carlo Simulation in Hotel Revenue Management. Czech Hospitality and Tourism Papers. Praha 8: Vysoká škola hotelová v Praze 8, spol. s r. o. 2015, pp. 18-25. ISSN 1801-1535.

doc. Mgr. Ing. Karel Chadt, CSc.; Ing. Martin Petř́íček, Ph.D. 


\section{CITLIVOSTNÍ KŘIVKA ROZHODOVACÍHO PROCESU PODNIKU}

Příspěvek se zaměřuje na problematiku využití citlivostní křivky jako ukazatel rizikovosti rozhodovacího procesu. Cílem článku je prezentovat možnost využití měření citlivosti rozhodovacího procesu v rámci problematiky využití kvantitativních metod v manažerském rozhodování. Přístup využívá měření citlivosti rozhodovacího modelu na jeho vstupní parametry. Celý rozhodovací proces je vícekriteriální a pro určení kompromisní varianty je využíván př́stup pomocí Weighted Sum Approach (WSA). Měření citlivosti poté probíhá tak, že je hledaný koeficient alfa, který určuje procentní změnu nutnou k volbě druhé nejlepší alternativní varianty. Kromě koefícientu alfa př́spěvek sestavuje citlivostní křivku. Tato křivka představuje změnu hodnotu výstupní funkce (s využitím metody WSA) při změnách vybraných vstupních parametrů rozhodovacího procesu. Pro sestavení citlivostní křivky je využit simulační přístup pomocí pravděpodobnostní simulace metodou Monte Carlo.

\section{DIE EMPFINDLICHKEITSKURVE DES ENTSCHEIDUNGSPROZESSES DES UNTERNEHMENS}

Der Beitrag konzentriert sich auf die Verwendung der Empfindlichkeitskurve als Indikator für das Risiko des Entscheidungsprozesses. Ziel des Artikels ist es zu präsentieren, wie man die Möglichkeit des Messens der Empfindlichkeit des Entscheidungsprozesses im Rahmen der Problematik der Verwendung der quantitativen Methoden in Management-Entscheidungen ausnutzt. Dieses Verfahren nutzt die Messung der Empfindlichkeit des Entscheidungsmodells in Bezug auf seine Eingabeparameter. Der gesamte Entscheidungsprozess ist multikriteriell und das Verfahren Weighted Sum Approach (WSA) wird genutzt, um die Kompromissvariante zu bestimmen. Das Messen der Empfindlichkeit besteht im Suchen des Koeffizienten Alpha. Neben dem Koeffizienten Alpha wird auch die Empfindlichkeitskurve in dem Beitrag aufgebaut. Diese Kurve repräsentiert die Veränderung des Wertes der Ausgangsfunktion (mit Verwendung des WSA), wenn die ausgewählten Eingabeparameter des Entscheidungsprozesses geändert werden. Der Wahrscheinlichkeitssimulationsansatz der Monte-Carlo-Methode wird genutzt, um die Empfindlichkeitskurve aufzubauen.

\section{KRZYWA WRAŻLIWOŚCI PROCESU DECYZYJNEGO W PRZEDSIĘBIORSTWIE}

Niniejszy artykuł skupia się na kwestii wykorzystania krzywej wrażliwości jako wskaźnika poziomu ryzyka procesu decyzyjnego. Celem opracowania jest przedstawienie możliwości wykorzystania pomiaru wrażliwości procesu decyzyjnego w ramach stosowania metod ilościowych w podejmowaniu decyzji zarządzających. Zaprezentowane rozwiązanie wykorzystuje pomiar wrażliwości modelu decyzyjnego na jego parametry wejściowe. Proces decyzyjny jest wielokryterialny i w celu wybrania wariantu kompromisowego stosowana jest metoda Weighted Sum Approach (WSA). Pomiaru wrażliwośćci dokonuje się poprzez poszukiwanie współczynnika alfa, który określa procentową zmianę niezbędną do wybrania drugiej najlepszej alternatywnej opcji. Oprócz współczynnika alfa w opracowaniu zbudowano krzywą wrażliwości. Krzywa ta przedstawia zmianę wartości funkcji wyjściowej (za pomocą metody WSA) w przypadku zmian wybranych parametrów wejściowych procesu decyzyjnego. Do budowy krzywej wrażliwości wykorzystano rozwiązanie symulacyjne przy pomocy symulacji prawdopodobieństwa metodą Monte Carlo. 